\title{
Evaluation of Flood Mitigation Effectiveness of Nature-Based Solutions Potential Cases with an Assessment Model for Flood Mitigation
}

\author{
Weicheng Lo ${ }^{1}$, Chih-Tsung Huang ${ }^{1}$, Meng-Hsuan $\mathrm{Wu}^{1, *}$, Dong-Jiing Doong ${ }^{1}{ }^{1}$, Leng-Hsuan Tseng ${ }^{2}$, \\ Chun-Hung Chen ${ }^{3}$ and Yen-Ju Chen ${ }^{3}$ \\ 1 Department of Hydraulic and Ocean Engineering, National Cheng Kung University, No. 1 University Road, \\ Tainan 701, Taiwan; lowc@mail.ncku.edu.tw (W.L.); n88051029@mail.ncku.edu.tw (C.-T.H.); \\ doong@mail.ncku.edu.tw (D.-J.D.) \\ 2 IHE Delft Institute for Water Education, Westvest 7, 2611 AX Delft, The Netherlands; k.tseng@un-ihe.org \\ 3 Water Resource Planning Institute, Water Resources Agency, Ministry of Economic Affairs, \\ No.1340 Jhong-Jheng Rd., Wu-fong, Taichung City 413, Taiwan; ch@wrap.gov.tw (C.-H.C.); \\ yenju@wrap.gov.tw (Y.-J.C.) \\ * Correspondence: chez_wu@mail.hyd.ncku.edu.tw
}

\section{check for} updates

Citation: Lo, W.; Huang, C.-T.; Wu, M.-H.; Doong, D.-J.; Tseng, L.-H.; Chen, C.-H.; Chen, Y.-J. Evaluation of Flood Mitigation Effectiveness of Nature-Based Solutions Potential Cases with an Assessment Model for Flood Mitigation. Water 2021, 13, 3451 https://doi.org/10.3390/ w13233451

Academic Editors: Momcilo Markus and Alban Kuriqi

Received: 2 November 2021

Accepted: 3 December 2021

Published: 5 December 2021

Publisher's Note: MDPI stays neutral with regard to jurisdictional claims in published maps and institutional affiliations.

Copyright: (c) 2021 by the authors. Licensee MDPI, Basel, Switzerland. This article is an open access article distributed under the terms and conditions of the Creative Commons Attribution (CC BY) license (https:/ / creativecommons.org/licenses/by/ $4.0 /)$.

\begin{abstract}
In recent years, climate change has been widely discussed around the world. The Intergovernmental Panel on Climate Change (IPCC) published the Sixth Assessment Report (AR6) in 2021, which stated that with the intensification of global warming, heavy rainfalls are becoming more severe and frequent. Economic development in recent years has also caused the proportion of impervious areas in urban regions to increase with the advancement of urbanization. When the two aforementioned factors are coupled together, the result is faster surface runoff speeds and reduced infiltration rates, which in turn result in worse flooding. Thus, water disaster mitigation is becoming a topic of great importance to developed and developing countries. This study examined five Nature-based Solutions (NbS) cases (A, B C, D, E) for the Nangang river in Taiwan. Case A is to design levees with a 100-year return period flood design standard. Under steady flow conditions, floods can be smoothly discharged downstream without any significant inundation in most situations. Case B and C used gabions with a 10-year return period flood design standard and discontinuous levees with a 25-year return period flood design standard, respectively. Though neither case is as effective in flood mitigation, both cases $B$ and $C$ can still reduce inundation from the flooding disaster relatively well. Case D is to dredge local areas of the main channel, but the steady flow simulation showed little flood mitigation effect. Case E is the implementation of "Room for the River", and employs main channel dredging and floodplain land grading to increase flood conveyance capacity. Case E provides good flood mitigation.
\end{abstract}

Keywords: nature-based solution; physiographic drainage-inundation model; flood mitigation

\section{Introduction}

The EU has actively promoted the use of Nature-based Solutions $(\mathrm{NbS})$ to respond to disasters with the hope that $\mathrm{NbS}$ can be as effective as traditional engineering methods in preventing disasters while providing benefits for the ecological environment. $\mathrm{NbS}$ is a concept proposed by the International Union for Conservation of Nature (IUCN) and the World Bank in 2008 [1], and aims to respond to social challenges such as climate change, food and water safety, and public health by adopting nature-based methods to achieve resource sustainability and conduct effective disaster risk management measures. It also aims to provide other benefits, such as promoting human welfare and sustaining ecological diversity [2]. The European Commission (EC) defines $\mathrm{NbS}$ as actions inspired by, supported by, or copied from nature that aim to improve current or provide better methods for dealing with environmental, social, and economic challenges [3]. The United 
Nations "World Water Assessment Programme" (WWAP) defines NbS as nature-inspired or mimicking actions that improve and contribute to water resource management [4]. In short, $\mathrm{NbS}$ refers to natural solutions and methods developed in response to various social or disaster challenges to achieve goals such as resource sustainability, effective disaster risk management, or disaster prevention and mitigation while providing social and environmental benefits simultaneously.

An ecosystem that is $100 \%$ natural may still not qualify as a $\mathrm{NbS}$. To determine whether it is an NbS, it is necessary to consider whether the system can use natural processes to achieve water-related purposes [3], such as flood mitigation and water reservation. According to the EC's definition, $\mathrm{NbS}$ must also be able to provide added values when addressing the social, environmental, or economic challenge that is the main objective [4]. The IUCN pointed out that any solution must be an integrated concept for addressing one or more social challenges to be called NbS, and the solution must be able to maintain or promote biodiversity and human welfare [2].

The $\mathrm{NbS}$ of flood mitigation can be divided into small and large-scale solutions, where the small-scale solution refers to solutions for urban or local areas, and large scale refers to those for suburbs, river basins, or regional areas. The concept and facilities of small-scale $\mathrm{NbS}$ are like those of low-impact development; in fact, most related research, including those on facilities such as green roofs, rainwater harvesting systems, permeable pavements, bio-retentions, and rain gardens [5-7], were called as such in the past. Past studies have confirmed that small-scale $\mathrm{NbS}$ have significant effects on urban disaster reduction during small rainfall (2-5-year return period rainfall), and permeable pavement is one of the most effective devices of small-scale NbS [8]. However, in extreme rainfall events (such as 50-year or 100-year return period rainfall), the effectiveness of the permeable pavements is very limited [5]. The commonly applied large-scale $\mathrm{NbS}$ include wetland restoration, river restoration, flood detention ponds, forest restoration, and "Room for the River" [9-11]. Though large-scale NbS is similar to traditional engineering methods, large-scale $\mathrm{NbS}$ not only achieves disaster reduction by restoring the original appearance of the landscape or using natural materials, but increases biodiversity, improves environmental resilience, or provides added value such as an amenity-oriented environment to the general public. As a result, this study believes that grey measures combined with both small and large-scale NBS should be the future trend [12,13].

The literature to date shows that various social challenges can be addressed through NbS. Reducing flood risk [14], reducing surface runoff [13], reducing exposure to soil erosion and landslides [15], and limiting coastal erosion [16] are a few examples of such challenges. Such benefits help in reaching sustainable water management.

The percentage of Taiwan's population that is exposed to more than three types of natural disasters is as high as $73 \%$, ranking first in the world [17]. With most of the population under such risks, disaster prevention, mitigation, and disaster recovery are considered to be some of the most important issues in need of addressing. In the past, Taiwan responded to floods with traditional engineering methods such as drainage systems planning and levee building. With the rapid development of cities resulting in impervious area increases, the scale and characteristics of flood disasters have become difficult to predict when coupled with the impact of extreme rainfall. Therefore, the concept of flood mitigation in Taiwan has gradually shifted from traditional flood control methods to comprehensive river basin management and land planning that integrates various engineering and non-engineering measures. For example, the concept of "Local Detention" reduces the required regional discharge capacity by lowering the water levels of fish farms and farmland in batches before typhoons and floods. This further reduces the probability of flooding during said events.

\section{Materials and Methods}

Figure 1 shows the process of effectiveness assessment of flood mitigation used in this study. After the study area was selected, the hydrological data (such as rainfall, water 
level, and discharge) and physiographic data (such as drainage system, flood mitigation structure, land use, and digital elevation model) were collected for the chosen area. Then, computational cells were built based on the data collected, and historical rainfall events were used for the calibration and verification of the PHD model. The calibrated and verified PHD model was then used to simulate the max inundation depth and area for various $\mathrm{NbS}$ cases. Finally, the NbS case most suitable for the case area was chosen according to the results of the simulation and the consensus of residents and stakeholders.

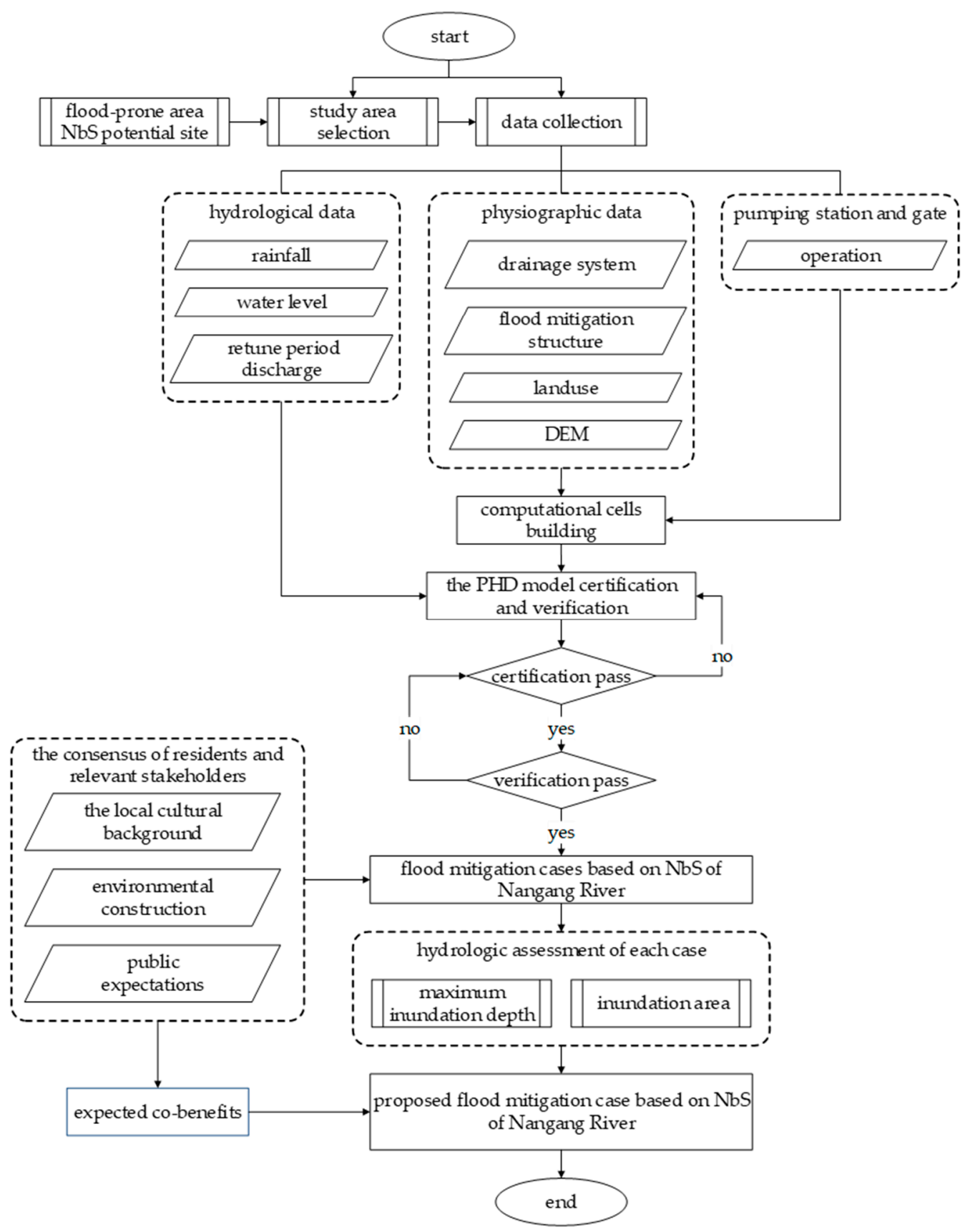

Figure 1. The flow chart of assessment effectiveness of flood mitigation.

\subsection{Study Area}

This study selected Nangang River in central Taiwan for the NbS flood and disaster mitigation case area. Nangang River is a tributary of the Wu River upstream, and it is the fourth-largest river in Taiwan. The length of the mainstream of Nangang River is about $37 \mathrm{~km}$, with a basin area of about $438 \mathrm{~km}^{2}$ and a population of about 130,000. The 
surrounding area of the basin is mainly used for agriculture. The largest tributary upstream of Nangang River is Mei River, with a drainage area of $136 \mathrm{~km}^{2}$ and accounting for about $1 / 3$ of the area of the Nangang River [18]. After the two rivers converge, they enter the mainstream of $\mathrm{Wu}$ River, where most of the basin topography decreases with the elevation from east to west as shown in Figure 2.

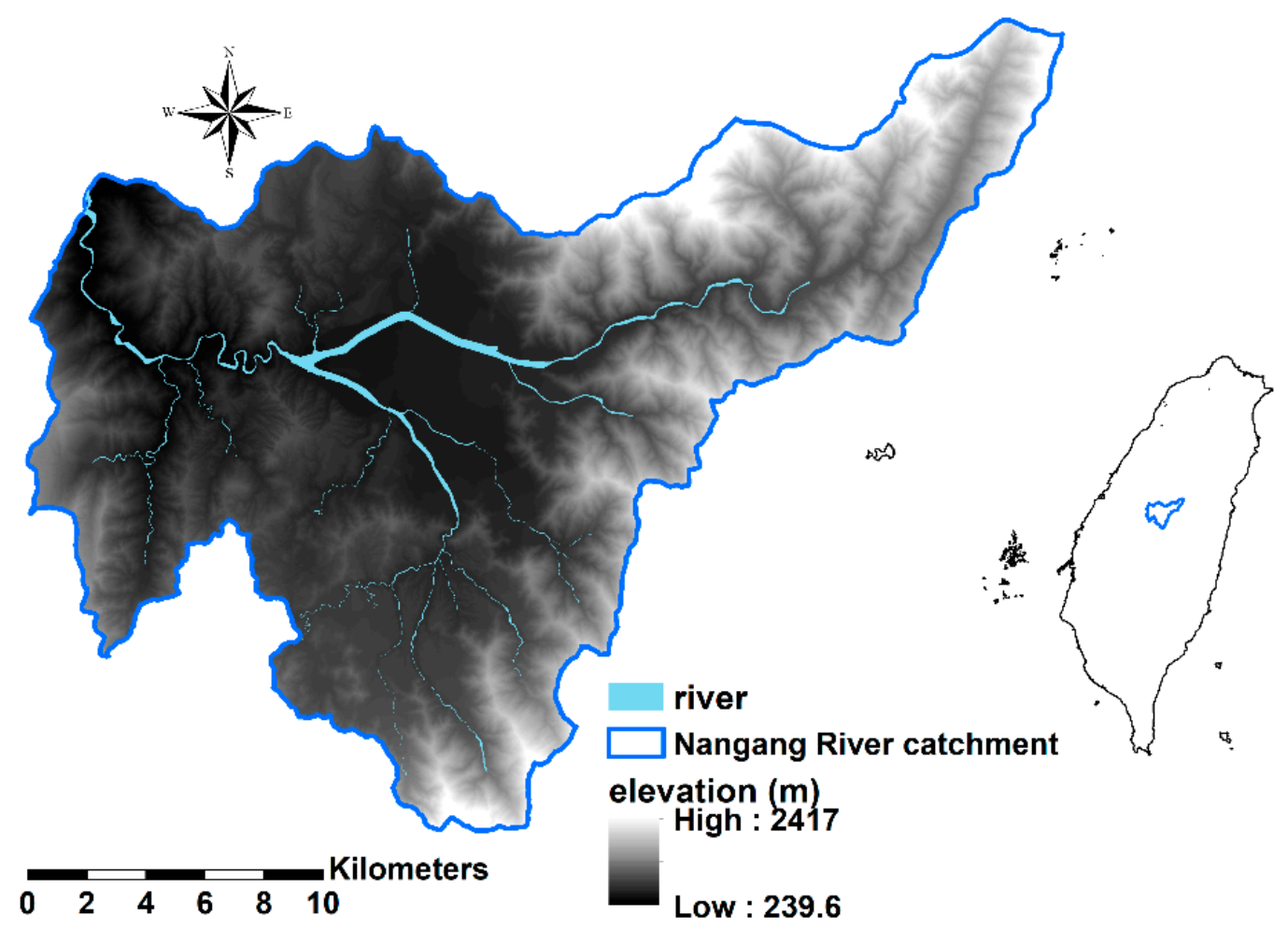

Figure 2. The elevation of Nangang River catchment.

Nangang River's main channel is narrow, and several major floods occurred in the past due to insufficient protection standards. A heavy rain event washed out a bridge in 2017, and another bridge was broken by heavy rain in 2018. Although new levees have been built, the local people believe that the addition of cement structures has impacted the overall landscape and the increasingly scarce wetland ecology. The local stakeholders hope the river can be protected in a natural way.

\subsection{Flood Mitigation Case Based on Nature-Based Solutions}

The considerations of $\mathrm{NbS}$ in disaster mitigation includes three aspects: water, people, and nature. Based on this, possible stakeholders in the Nangang River case include the competent authority, local residents, and related non-governmental organizations. To consolidate the consensus of local residents and relevant stakeholders on river governance and environmental construction, the 3rd River Management Office conducted a total of three interviews in March, July, and September 2020. In the first interview, residents mentioned that the channel capacity is too small and often results in flooding after heavy rain. They suggested that the 3rd River Management Office expropriate the land instead of building new levees to achieve the objective of ecological resource protection and flood mitigation. In the second interview, residents and stakeholders mentioned that they want to know the flood mitigation effectiveness of each flood mitigation plan for comparison. They also called for promenades to be built or local tree species to be planted along with the planned flood mitigation facilities to satisfy protection standards and enrich the landscape simultaneously. In the third interview, residents and stakeholders mentioned that discontinuous levees and wildlife corridors could be set up to increase permeability 
and reduce the impact on the ecological environment and the landscape. They suggested that the competent authority should propose feasible environmental solutions based on the local cultural background, environmental construction, and public expectations. Based on the interview results, this research conducted a site survey and proposed five cases, as shown in Table 1.

Table 1. Description of the 5 Nangang River NbS cases.

\begin{tabular}{|c|c|c|c|}
\hline Case & Name & Content & Description \\
\hline A & Extend the existing levees & $\begin{array}{l}\text { Adopt the } 100 \text {-year } \\
\text { return period flood level } \\
\text { as planned levee } \\
\text { top elevation }\end{array}$ & $\begin{array}{l}\text { High-strength flood } \\
\text { mitigation protection } \\
\text { engineering }\end{array}$ \\
\hline $\mathrm{B}$ & Extend the existing levees & $\begin{array}{l}\text { Adopt the 10-year return } \\
\text { period flood level as } \\
\text { planned levee } \\
\text { top elevation }\end{array}$ & $\begin{array}{l}\text { Low-strength flood } \\
\text { mitigation protection } \\
\text { engineering. }\end{array}$ \\
\hline $\mathrm{C}$ & Discontinuous levees & $\begin{array}{l}\text { Set up discontinuous } \\
\text { levees with a } 25 \text {-year } \\
\text { return period flood level } \\
\text { as planned levee top } \\
\text { elevation, and set up a } \\
\text { wildlife corridor at the } \\
\text { levee opening }\end{array}$ & $\begin{array}{l}\text { Using discontinuous levees } \\
\text { and wildlife corridors to } \\
\text { increase permeability and } \\
\text { reduce the impact on the } \\
\text { ecological environment } \\
\text { and landscape }\end{array}$ \\
\hline $\mathrm{D}$ & Dredging & $\begin{array}{l}\text { Dredge } 1 \mathrm{~m} \text { of the } \\
\text { riverbed on selected } \\
\text { areas of the main channel }\end{array}$ & $\begin{array}{l}\text { Dredged soil can be placed } \\
\text { on both sides of the levees } \\
\text { and used to plant local } \\
\text { plant species. }\end{array}$ \\
\hline $\mathrm{E}$ & Room for the River & $\begin{array}{l}\text { Plan a "Room for the } \\
\text { River" with an area of } \\
\text { about } 36.35 \text { hectares }\end{array}$ & $\begin{array}{l}\text { Plan lower elevation areas } \\
\text { as detention wetlands and } \\
\text { higher elevation areas as } \\
\text { recreational facilities. Can } \\
\text { be combined with local } \\
\text { plant species to enrich the } \\
\text { surrounding landscape. }\end{array}$ \\
\hline
\end{tabular}

\subsection{The Flood Mitigation Assessment Model}

To understand the impact of the above cases on the Nangang River, numerical models are used to simulate and compare the changes in surface runoff of each case. As surface runoff is related to the temporal and spatial distribution of rainfall and surface water, when performing rainfall runoff simulation, the hydrological and physiographic conditions in the case area should be considered. This study adopts the Physiographic Drainage-inundation (PHD) model, which is widely used in Taiwan to simulate rainfall runoff. The PHD model can be used for flooding vulnerability assessment [19], detention pond operation optimization [20], and the assessment of the impact of extreme weather under climate change [21]. Its governing equation is shown as follows [22]:

$$
A s_{i} \frac{d h_{i}}{d t}=P e_{i}+\sum_{k} Q_{i, k}\left(h_{i}, h_{k}\right)
$$

where $A s_{i}$ is the area of the $i$ cell; $Q_{i, k}$ denotes the discharge from the $k$ cell into its neighboring $i$ cell. Discharge is positive when flowing into the $i$ cell and negative when flowing out of the $i$ cell; $h_{i}$ and $h_{k}$ represent the water levels of the $i$ and $k$ cells at time $t$ respectively; and $P e_{i}$ expresses the effective rainfall volume per unit time in the $i$ cell, which is equal to the effective rainfall per unit time in the $i$ cell multiplied by its area $A s_{i}$. 
Total effective rainfall $P^{\prime}$ can be calculate by the SCS-CN method; the equation can be writen as [23]:

$$
\begin{gathered}
P^{\prime}=\frac{\left(P-I_{a}\right)^{2}}{\left(P-I_{a}\right)+S} \\
S=\frac{25400-254 C N}{C N}
\end{gathered}
$$

$P$ is the total rainfall; $I_{a}$ is the initial abstraction, including depression storage, intercepting, and evapotranspiration; and $C N$ is the dimensionless curve number that is determined by soil type, type of vegetation cover, land use, hydrologic condition, antecedent moisture condition, and climate of the watershed [23]. In this study, $I_{a}=0.2 S$ and CN is between 25 and 98 .

The flow discharge between adjacent cells in the model can be divided into the river flow type, the weir flow type, and the pumping station type.

\subsubsection{River Flow Type}

If there are no flow obstacles in the exchange of water between two adjacent cells, it is regarded as an overland flow, where the Manning formula can be used to calculate the water flow through the boundary of the two cells. From $i$ cell, the flow from $k$ cell to $i$ cell is:

$$
\begin{gathered}
Q_{i, k}=\frac{h_{k}-h_{i}}{\left|h_{k}-h_{i}\right|} \cdot \Phi\left(\overline{h_{i, k}}\right) \cdot \sqrt{\left|h_{k}-h_{i}\right|} \text { for } \frac{\partial Q_{i, k}}{\partial h_{i}} \leq 0 \\
Q_{i, k}=\Phi\left(h_{k}\right) \cdot \sqrt{\left|h_{k}-h_{i}\right|} \text { for } \frac{\partial Q_{i, k}}{\partial h_{i}}>0
\end{gathered}
$$

where $\overline{h_{i, k}}$ is the water level at the boundary of $i$ and $k$ cells.

$$
\overline{h_{i, k}}=h_{k}+(1-\alpha) h_{i}, 0 \leq \alpha \leq 1
$$

and $\Phi(h)$ :

$$
\Phi(h)=\frac{A(h) R(h)^{2 / 3}}{n \sqrt{\Delta x}}
$$

where $\Delta x$ is the distance between the center of the $i$ and $k$ cells; $n$ is the Manning roughness coefficient of overland flow between the two neighboring cells; and $A, R$ the hydraulic area and radius at the border between the two neighboring cells, respectively. When $h_{k}>h_{i}$ and $h_{i}$ is decreasing, we can assume that $\alpha=1$ in Equation (4), to negate the influence of $h_{i}$ and calculate the water flow from the $k$ cell to $i$ cell with Equation (3).

\subsubsection{Weir Flow Type}

If the areas are divided by hydraulic or artificial structures, such as roadways, levees, field ridges, or banks, then the border may be treated as a broad-crested weir, and the weir flow formula can be used to obtain flow from one cell to the other. Such flow exchange between cells is regarded as the weir flow type. If $h_{k}>h_{i}$, then there are two possible situations, the free weir, and the submerged weir, as shown in Figure 3. When the flow condition is the free weir, the status of the flow will be critical, and when the flow condition is submerged weir, the status of the flow will be sub-critical. Below are the formulas for both flow conditions:

1. Free weir

$$
\left(h_{i}-h_{w}\right)<\frac{2}{3}\left(h_{k}-h_{w}\right), Q_{i, k}=\mu_{1} b \sqrt{2 g}\left(h_{k}-h_{w}\right)^{\frac{3}{2}}
$$

2. Submerged weir

$$
\left(h_{i}-h_{w}\right) \geq \frac{2}{3}\left(h_{k}-h_{w}\right), Q_{i, k}=\mu_{2} b \sqrt{2 g}\left(h_{i}-h_{w}\right)\left(h_{k}-h_{i}\right)^{\frac{1}{2}}
$$


where $h_{w}$ is the weir height, which is the roadway, levees or ground height; $b$ is the effective width of the weir top, which is equivalent to the intersection length of two adjacent cells; $g$ is gravitational constant; and $\mu_{1}$ and $\mu_{2}$ are the weir coefficients of the free and submerged weirs, respectively. $\mu_{1}=0.36-0.57$. In this study, $\mu_{1}=0.4$ and $\mu_{2}=2.6 \mu_{1}[24]$ are used.

- Submerged weir Free weir

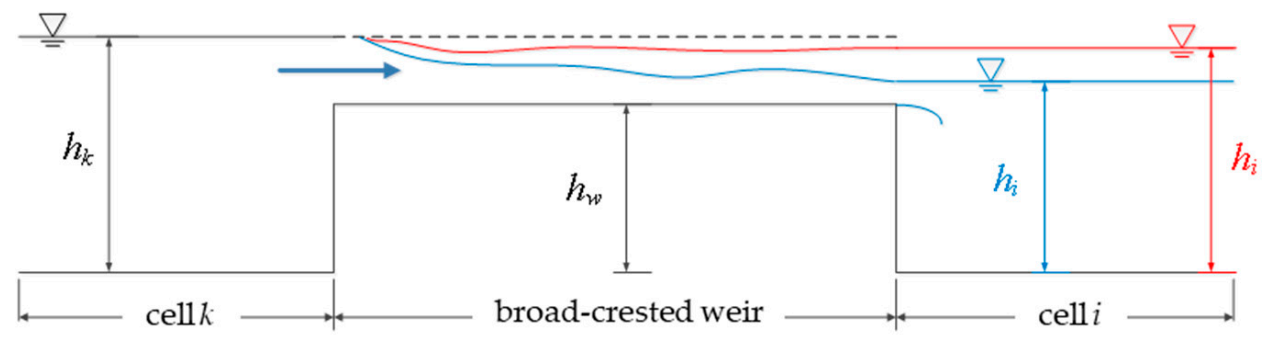

Figure 3. The free weir and the submerged weir flow.

\subsubsection{Pumping Station Type}

If a pumping station is set up in the $i$ cell, the water exchange between two adjacent cells is based on the operation principle of the pumping station. When the water level in the $i$ cell exceeds the initial water-pumping level, the water exchange between the cells will be carried out according to the pumping capacity of the pump.

If the water level in $i$ cell exceeds the initial water-pumping level:

$$
h_{i} \geq h_{p}, Q_{i, k}=Q_{p} \cdot \Delta t
$$

If the water level in $i$ cell is below the initial water-pumping level:

$$
h_{i}<h_{p}, Q_{i, k}=0
$$

where $h_{p}$ is the initial water-pumping level of the pumping station operation rules, $\Delta t$ is the time step, and $Q_{p}$ is the pumping rate during $\Delta t$.

The PHD model is based on the basic equation of the quasi-2D discharge where the mathematical model is established by the explicit finite-difference method. After the discretization of Equation (1) via the use of the explicit finite difference method, we can arrive at Equation (12):

$$
\Delta h_{i}=\left[P e_{i}+\sum Q_{i, k}\left(h, h_{k}\right)\right] \Delta t / A s_{i}
$$

$\Delta h_{i}$ is the water level increment during time.

\subsection{Model Certification and Verification}

This study built a computational cell based on the hydrological and physiographic data of the case area. The computational cell covers an area of $2046 \mathrm{~km}^{2}$, with a total of 9804 cells, as shown in Figure 4.

This study took the heavy rain event from June 2016 as a certification case of the PHD model and used the Nash-Sutcliffe efficiency (NSE) coefficient and root mean square error (RMSE) for checking the value of the model accuracy. Another heavy rain event from May 2019 was taken as a verification case, and the simulation results of both events are as shown in Figure 5. The NSE and RMSE values of the heavy rain event in June 2016 are 0.78 and $0.15 \mathrm{~m}$, and the heavy rain event in May 2019 has values of 0.68 and $0.47 \mathrm{~m}$, respectively. As the NSE values of both events exceeded 0.5, we concluded that the PHD model can reasonably simulate the phenomenon of runoff in the case area. 


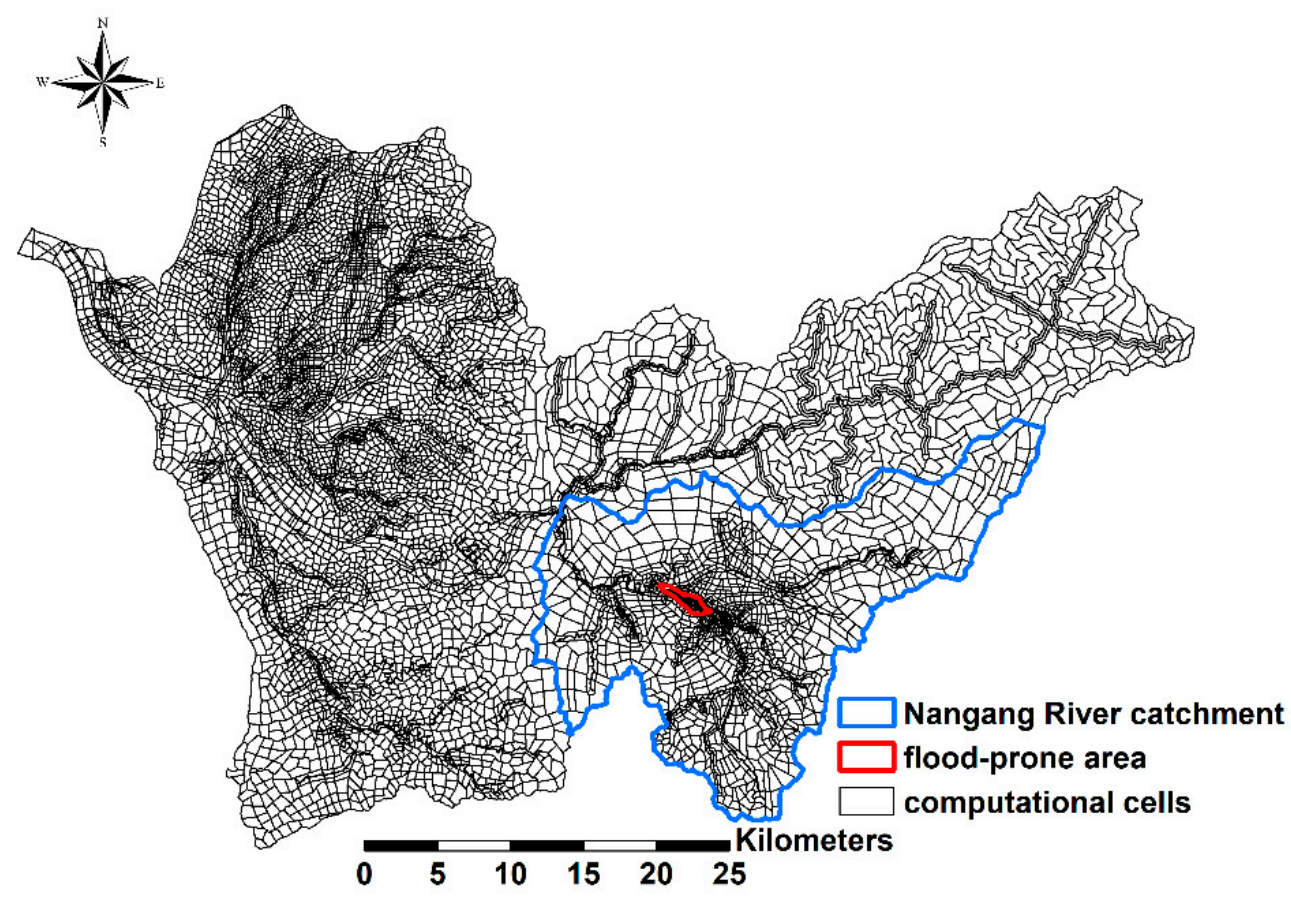

Figure 4. Computational cells.

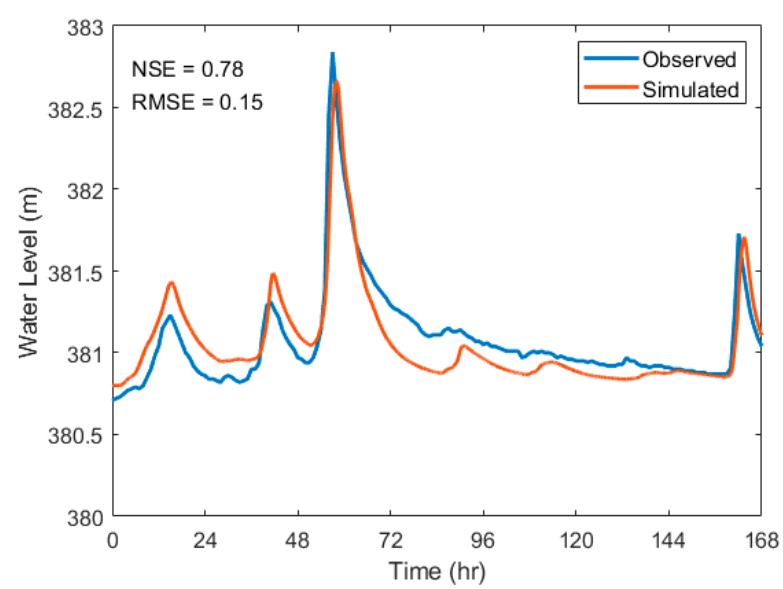

(a)

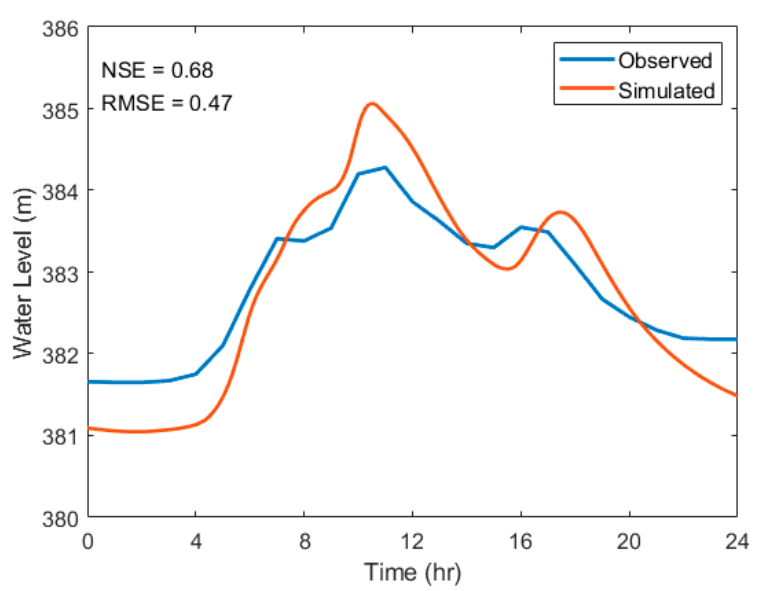

(b)

Figure 5. The comparison between simulated and observed water level. (a) Heavy rain event from June 2016; (b) Heavy rain event from May 2019.

\subsection{Boundary Condition}

As this study was conducted from a planning perspective, the more conservative steady stream condition was chosen for the upstream boundary flow condition.

The flow discharge of the Nangang River and the tributary of the Mei River during each return period are shown in Table 2 in accordance to the Nangang River planning report [15]. The flow discharge will be used as the upstream boundary condition for steady flow simulation in the future. 
Table 2. Upstream inflow conditions for different return periods.

\begin{tabular}{ccccc}
\hline Flow Discharge & 5-Year Return Period & 10-Year Return Period & 25-Year Return Period & $\begin{array}{c}\text { 100-Year Return } \\
\text { Period }\end{array}$ \\
\hline Mei River & 960 & 1240 & 1620 & 2230 \\
Nangang River & 910 & 1200 & 1570 & 2200 \\
\hline
\end{tabular}

Units: cms.

\section{Results and Discussion}

\subsection{Hydrologic Assessment for Each Case}

\subsubsection{Current Situation}

To compare the current situation with the flood mitigation of each case, the hydrography simulation under each return period was carried out based on the current situation of the case area. The results of the simulations are shown in Figure 6.

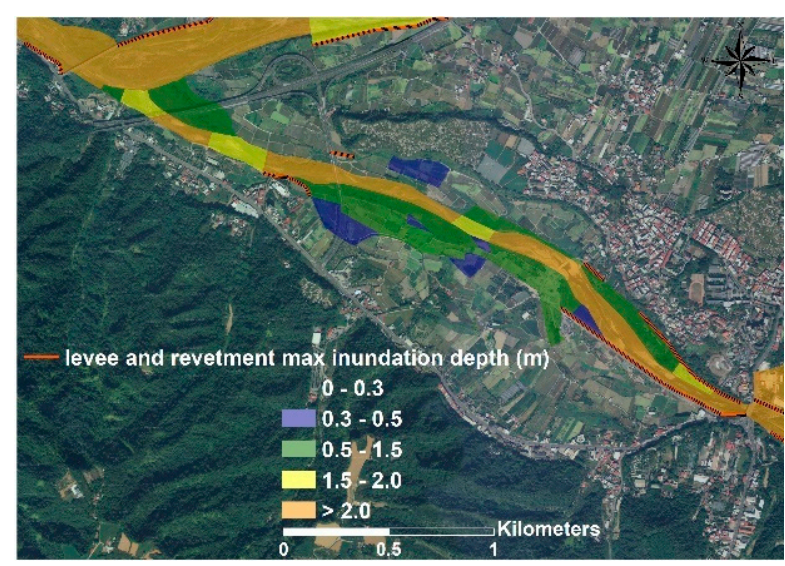

(a)

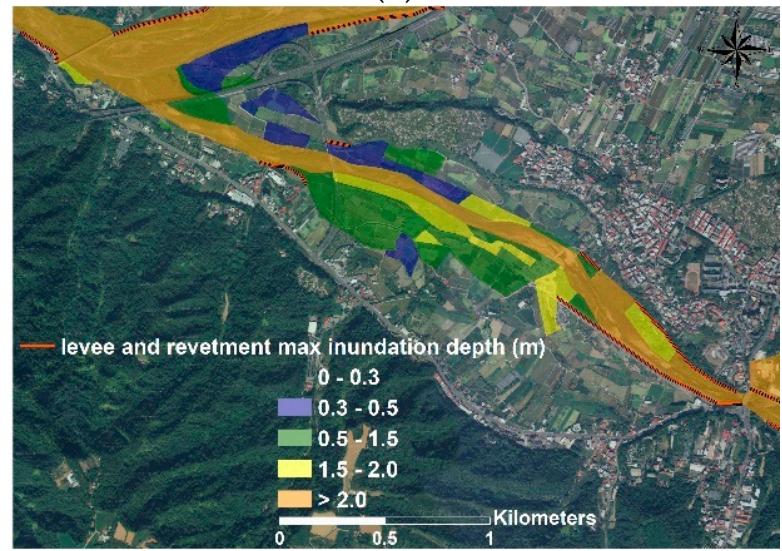

(c)

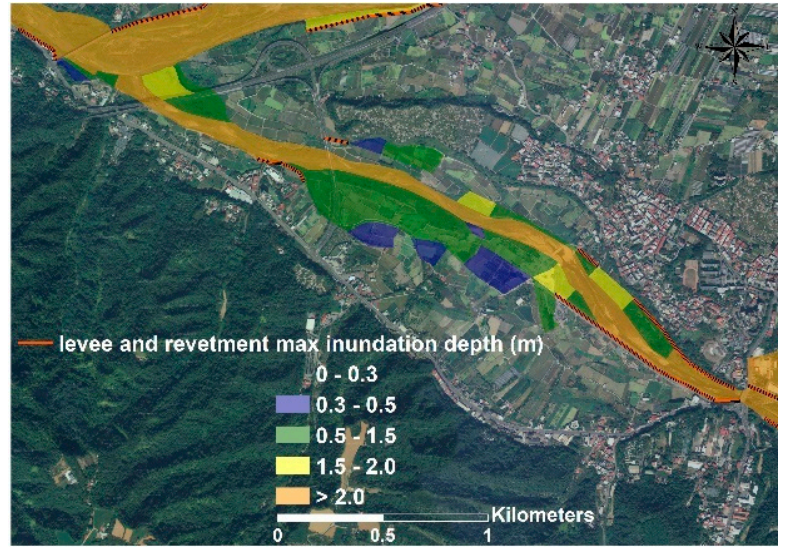

(b)

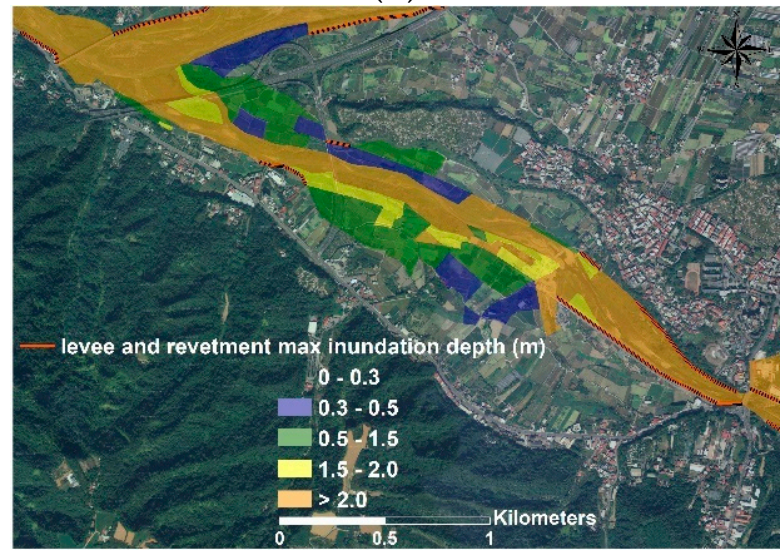

(d)

Figure 6. Maximum inundation depth of current situation. (a) 5-year return period flood; (b) 10-year return period flood; (c) 25-year return period flood; (d) 100-year return period flood.

When the return period was 5 years, the maximum inundation depth of the main channel was between 1.5 and $2 \mathrm{~m}$. When the return period was greater than 5 years, the maximum inundation depth of the main channel exceeded $2 \mathrm{~m}$. The topography of the left bank in the case area is relatively lower, so under current conditions the inundation area on the left bank increases with increases in upstream flow. There were some inundation areas on the floodplains of the right bank, with the maximum inundation water depth being 0.3 to $0.5 \mathrm{~m}$ when the return period is 5 years. As the return period increased, the inundation area and the maximum inundation depth increased, with maximum inundation depth on 
the floodplains of the right bank exceeding $2 \mathrm{~m}$ when the return period was 100 years. The floodplains of the left bank had lower elevation, and thus had worse flooding. The maximum inundation depth of 5-year return period floods was 0.5 to $1.5 \mathrm{~m}$. When the return periods were 10 and 25 years, the inundation area of the left bank increased further, and maximum inundation depth reached 1.5 to $2 \mathrm{~m}$. When the return period was 100 years, the maximum inundation depth exceeded $2 \mathrm{~m}$. The topography of the left bank in the case area is relatively lower, so under current conditions, with the increase in upstream flow, the inundation areas of the left bank also increase.

\subsubsection{Case A}

Case A proposes to extend the existing levees downstream by $1500 \mathrm{~m}$ to meet the 100-year return period flood design standard. According to the results simulated, after the existing levees were extended downstream, the inundation of the left bank can be significantly improved, as shown in Figure 7.

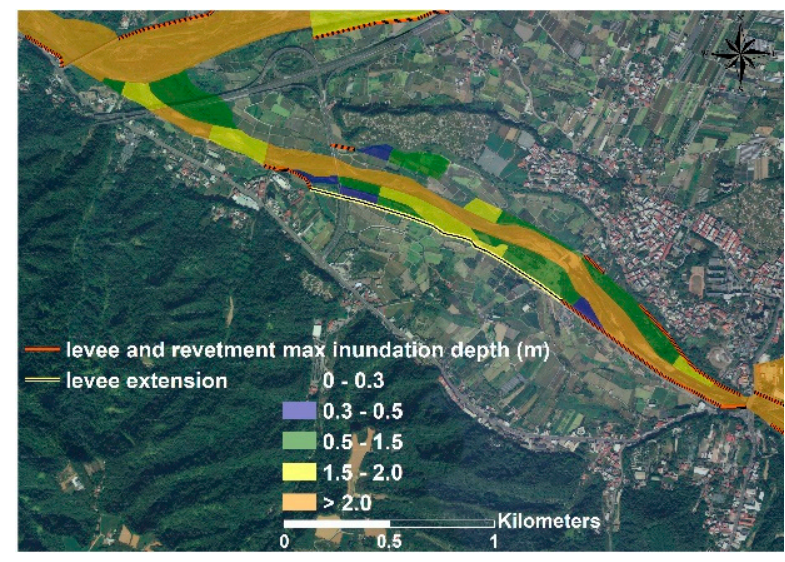

(a)

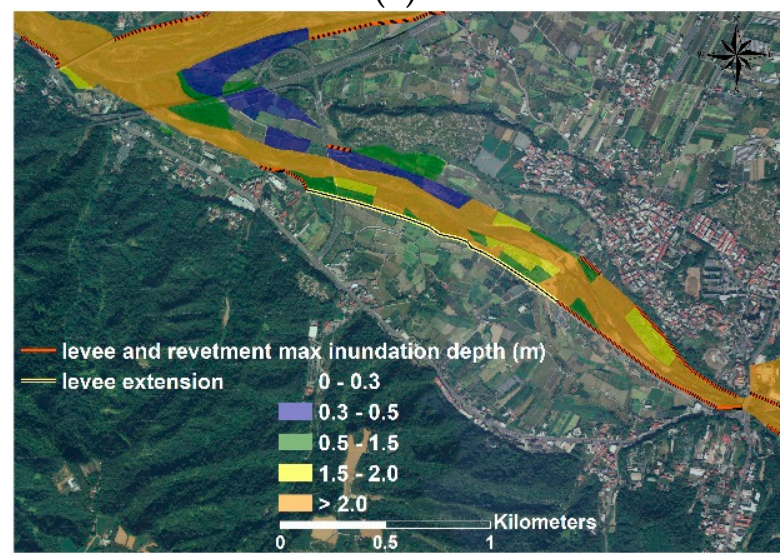

(c)

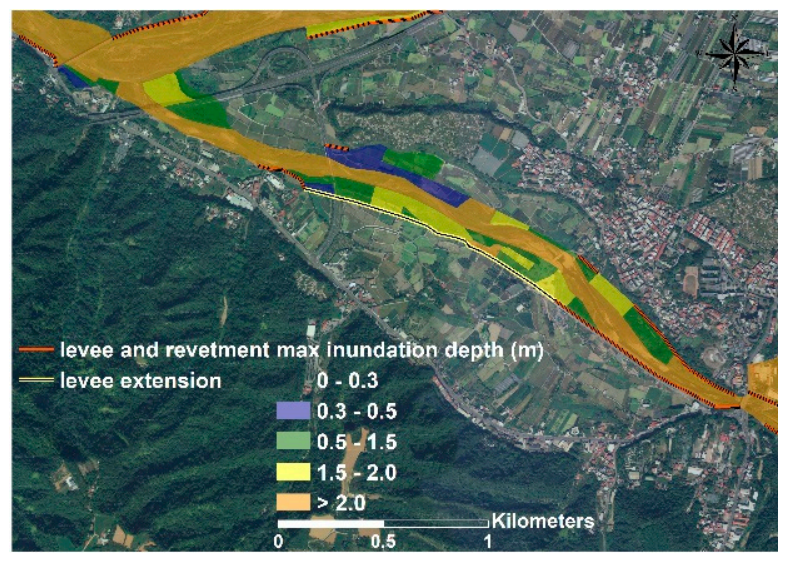

(b)

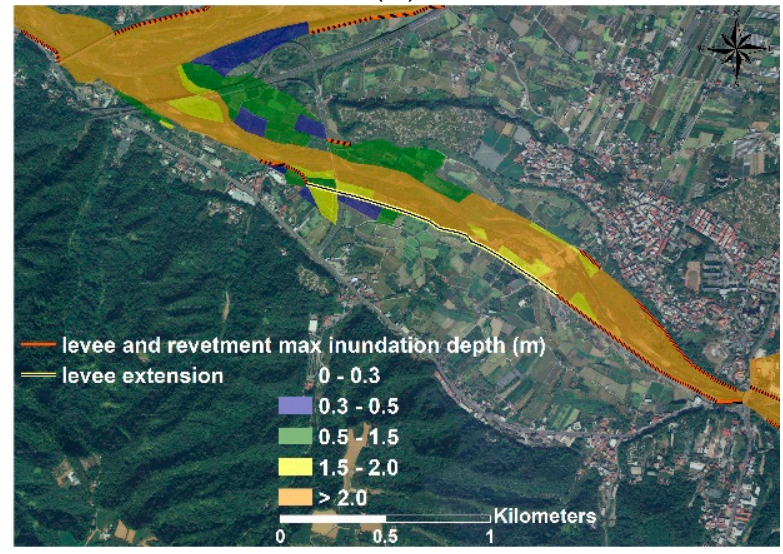

(d)

Figure 7. Maximum inundation depth of case A. (a) 5-year return period flood; (b) 10-year return period flood; (c) 25-year return period flood; (d) 100-year return period flood.

Inundation only occurred in low-lying parts of the left bank when the case area was subject to a 100-year return period flood. The water depth of the main channel rises slightly for all return periods when compared to the current situation, while the inundation of the right bank largely remains unchanged for all return periods.

\subsubsection{Case B}

Both cases B and A extend the existing levees downstream by $1500 \mathrm{~m}$, but the 10-year return period was chosen for the levee flood design standard in case B. The results simulated are as shown in Figure 8. 
Inundation on the left bank still occurs, with the inundation area larger and inundation depth deeper for case B when compared to case $\mathrm{A}$. The maximum water depth of inundated areas of the left bank was $0.3 \mathrm{~m}$ to $1.5 \mathrm{~m}$ for a return period of 5 years, $1.5 \mathrm{~m}$ to $2 \mathrm{~m}$ for return periods of 10 years and 25 years, and over $2 \mathrm{~m}$ for a return period of 100 years. Inundation of the right bank largely remained unchanged from the current situation.

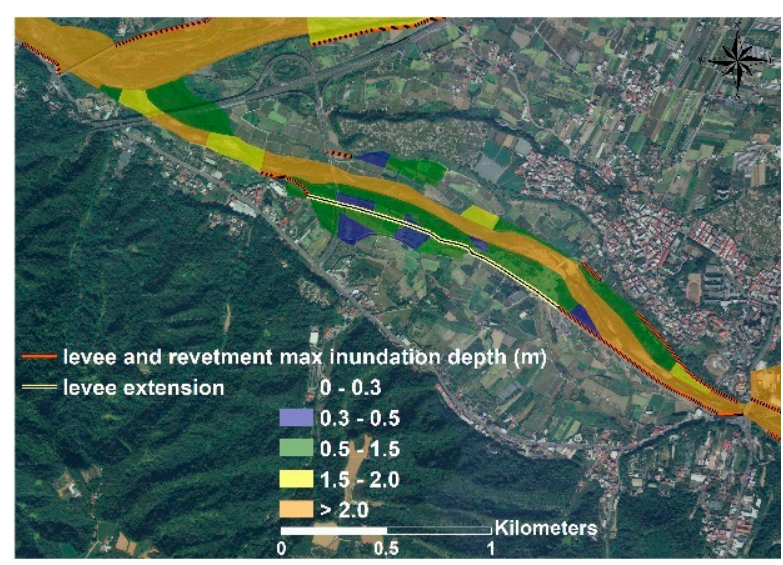

(a)

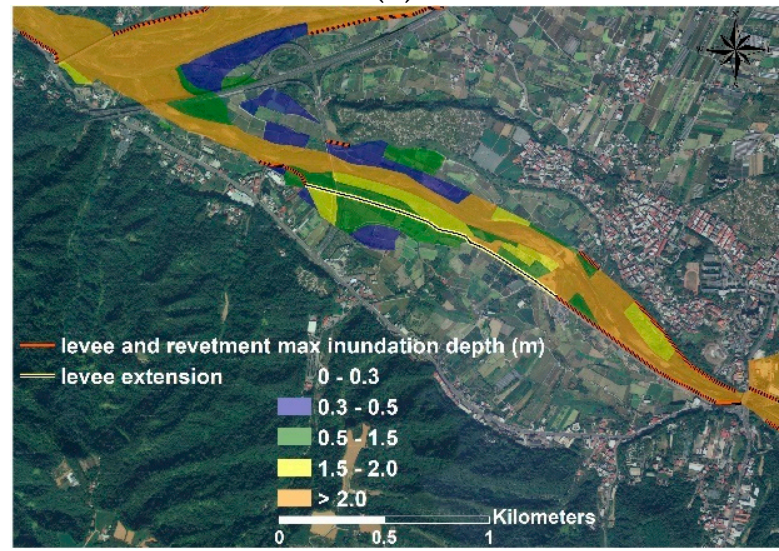

(c)

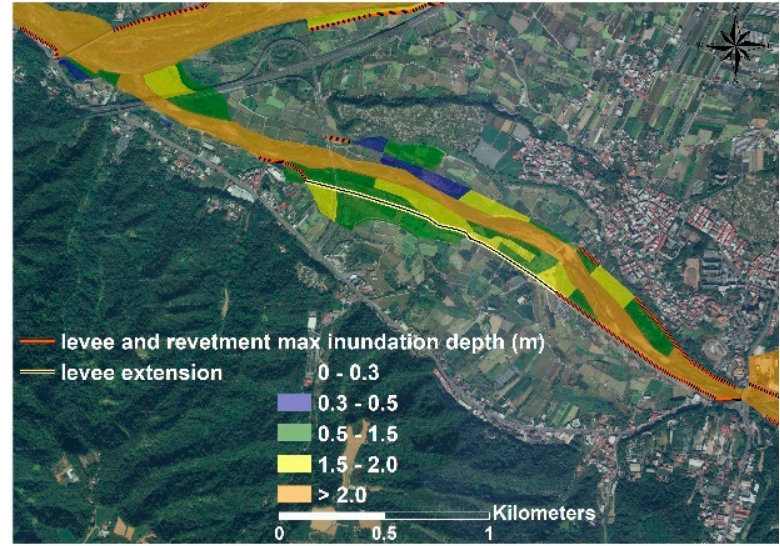

(b)

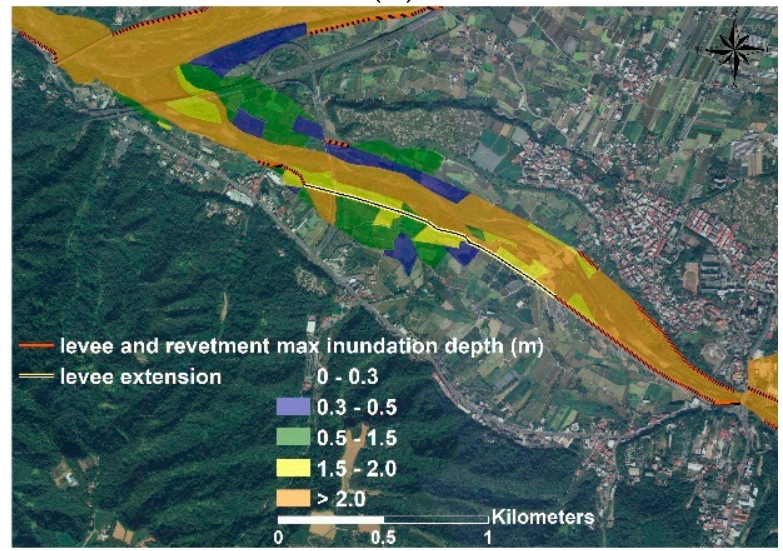

(d)

Figure 8. Maximum inundation depth of case B. (a) 5-year return period flood; (b) 10-year return period flood; (c) 25-year return period flood; (d) 100-year return period flood.

\subsubsection{Case C}

Case $\mathrm{C}$ is a concept proposed by the 3rd River Management Office. It proposed using the solution assembled from the interviews with the residents and stakeholders. The case consisted of building $600 \mathrm{~m}$ of discontinuous levees with a 25-year return period flood design standard on the left bank of the river, and adding a wildlife corridor to the discontinuous levees. The simulated results are shown in Figure 9.

It was found in the simulation that the inundation area of the left bank became smaller than the current situation after the implementation of case $C$. The inundation depth of the left bank also reduced. The inundation depth of the right bank, however, remained similar to the current situation. Areas not covered by the levees of the left bank had maximum inundation depths of $0.3 \mathrm{~m}$ to $1.5 \mathrm{~m}$ for 5 to 25-year return period floods, with the inundation area increasing with the length of the return period. When the return period was 100 years, the maximum inundation depth reached 1.5 to $2 \mathrm{~m}$.

\subsubsection{Case D}

Case D refrained from altering current structures, instead choosing to dredge $1 \mathrm{~m}$ of soil from the riverbed for $200 \mathrm{~m}$ both upstream and downstream of the bridge sup- 
ports. The results of the simulation are shown in Figure 10, and show that main channel dredging makes no significant difference in inundation of the case area. The inundation area and maximum inundation depth of case D is similar to the current situation for all return periods.

\subsubsection{Case $\mathrm{E}$}

Case E proposed to plan a "Room for the River" using an area of about 36.35 hectares in size from the case area itself and areas in the immediate vicinity. "Room for the River" includes both main channel dredging and floodplain grading in this situation. The results of the simulation are shown in Figure 11, where the main channel elevation has been dredged and the flooding capacity increased.

In the simulations, no inundation occurred for floods with return periods below 100 years after the implementation of case E. When the return period was 5, 10, or 25 years, the floodwater distribution almost covered the "Room for the River" area entirely. The main channel depth was above $2 \mathrm{~m}$ for all return periods, with the floodplain inundation depth at 0.5 to $1.5 \mathrm{~m}$ when under a 5-year return period, 1.5 to $2.0 \mathrm{~m}$ when under a 10 -year return period, and exceeding $2 \mathrm{~m}$ when under a 25 -year return period. When the return period was 100 years, the inundation area exceeded that of the "Room for the River" area, and the maximum inundation depth reached 1.5 to $2 \mathrm{~m}$.

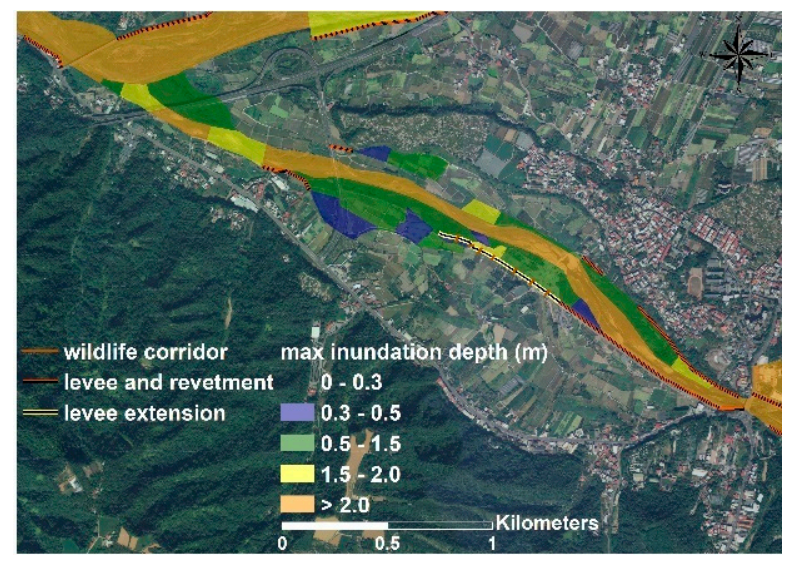

(a)

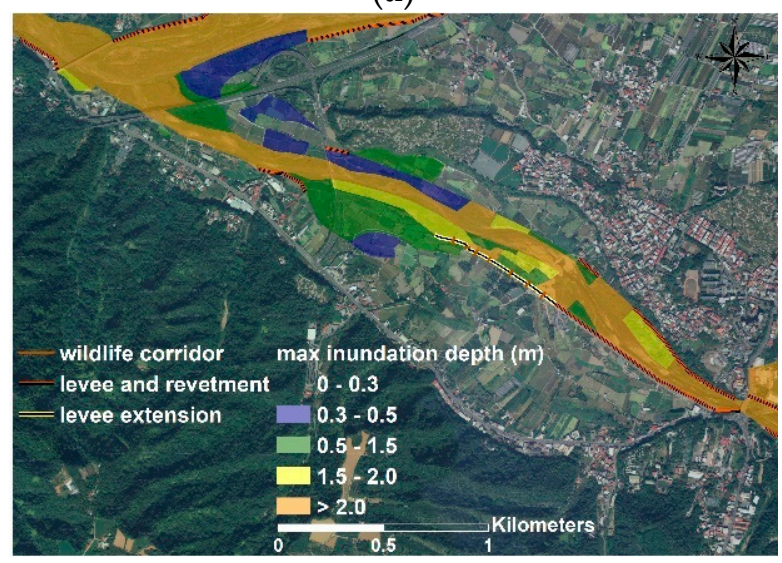

(c)

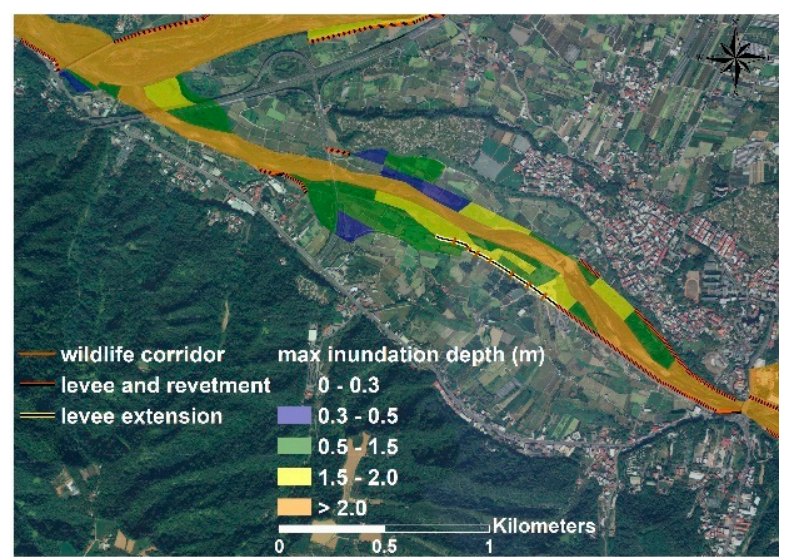

(b)

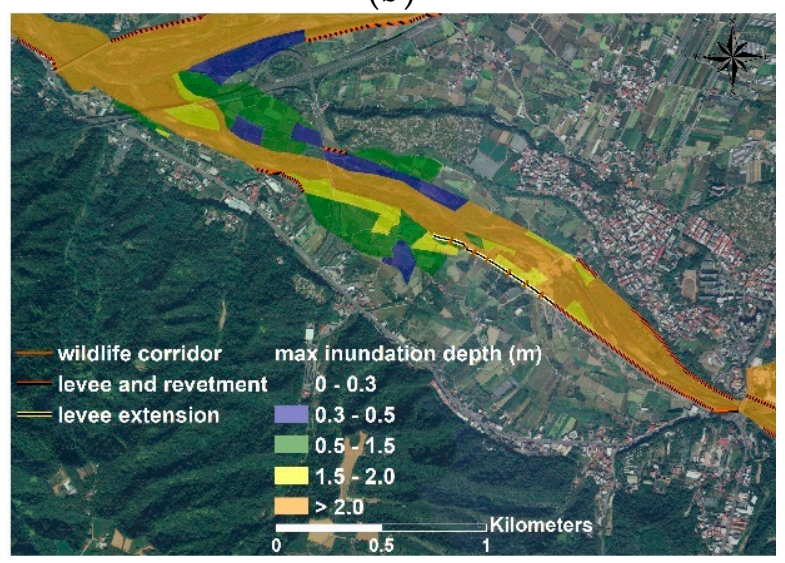

(d)

Figure 9. Maximum inundation depth of case C. (a) 5-year return period flood; (b) 10-year return period flood; (c) 25-year return period flood; (d) 100-year return period flood. 


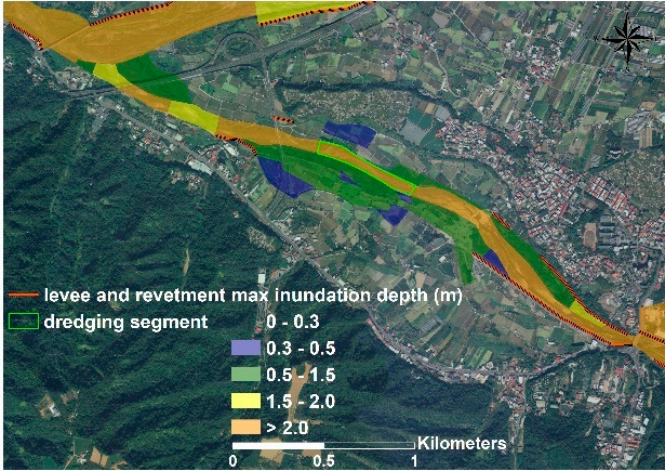

(a)

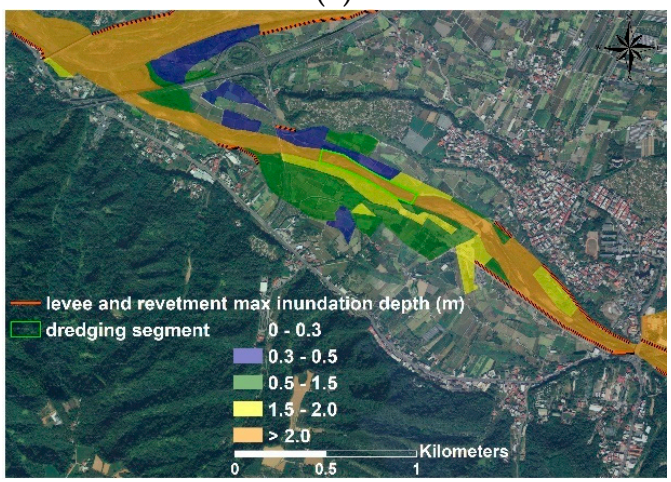

(c)

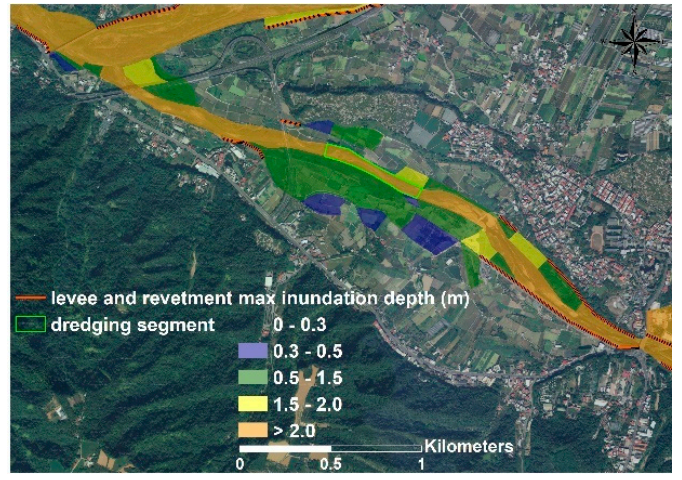

(b)

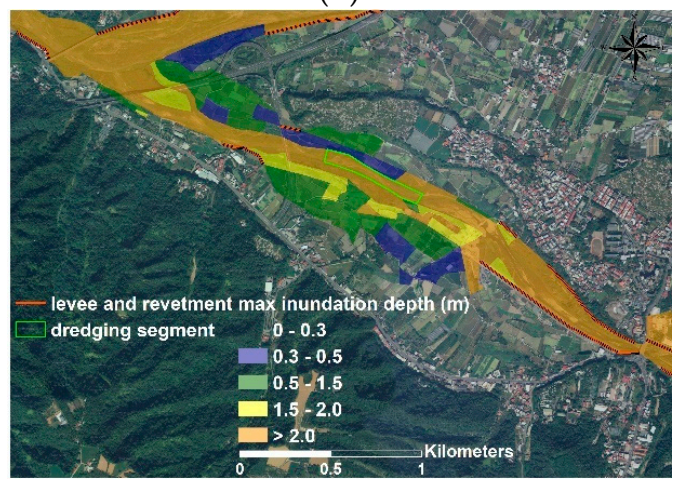

(d)

Figure 10. Maximum inundation depth of case D. (a) 5-year return period flood; (b) 10-year return period flood; (c) 25-year return period flood; (d) 100-year return period flood.

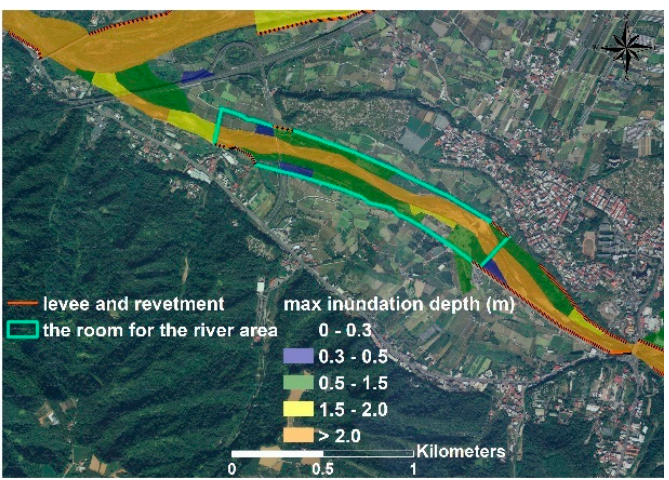

(a)

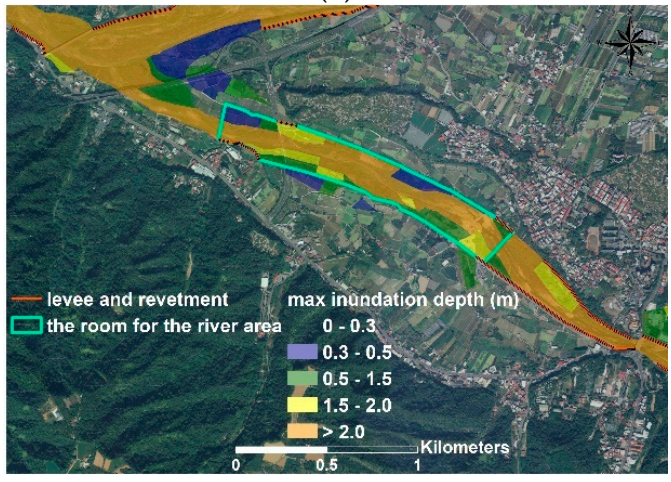

(c)

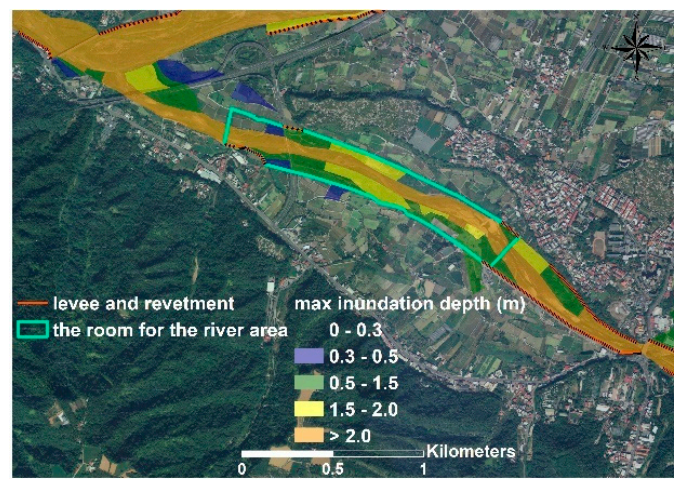

(b)

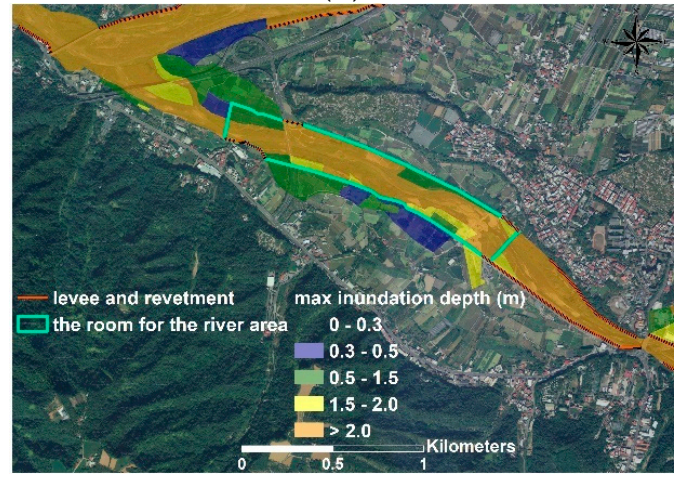

(d)

Figure 11. Maximum inundation depth of case E. (a) 5-year return period flood; (b) 10-year return period flood; (c) 25-year return period flood; (d) 100-year return period flood. 


\subsection{Inundation Area Comparison of Each Case}

The total inundation area (areas with maximum inundation depth above $0.3 \mathrm{~m}$ ) of the current situation and of the five proposed cases is shown in Table 3. The total inundation areas of case A when under the 25-year and 100-year return periods were 0.12 and 5.2 hectares, respectively, which is less than the total inundation area of the current situation and demonstrates that case A has good flood mitigation. Cases B and C are better in terms of total inundation area when compared with the current situation, but their flood mitigation effects were not as profound as case A. Case D increased the capacity of the main channel through dredging, but as this action has little effect when under the steady flow condition, the total inundation area remained unchanged from the current situation. Case E increased the maximum river capacity through land expropriation, dredging, and land grading. When under the 25-year and 100-year return periods, the total inundation areas were 4.3 and 13.96 hectares, respectively. The flood mitigation effect of case $E$ was second only to case A when under the 25-year return period, and roughly equivalent to case $\mathrm{C}$ when under the 100 -year return period.

Table 3. Total inundation area of different return periods of each case.

\begin{tabular}{ccccc}
\hline Flow Discharge & 5-Year Return Period & 10-Year Return Period & 25-Year Return Period & 100-Year Return Period \\
\hline Current Situation & 10.72 & 17.65 & 19.34 & 25.05 \\
Case A & 0.00 & 0.00 & 0.12 & 5.20 \\
Case B & 8.60 & 8.71 & 11.44 & 15.74 \\
Case C & 7.96 & 7.96 & 10.14 & 13.16 \\
Case D & 10.72 & 17.65 & 19.34 & 25.05 \\
Case E & 1.64 & 2.41 & 4.30 & 13.96 \\
\hline
\end{tabular}

Unit: Hectare.

\subsection{Case Selection}

As can be seen from the results of the simulations, under all four return periods case A surpassed all other cases in the reduction of inundation area size, i.e., case A had the best flood mitigation in all simulated situations. The rest of the cases are ranked in descending order as case E, case C, case B, and case D in terms of flood mitigation. Case D had little effect under the steady flow condition.

All NbS cases consider benefitting the protection of resident life and property in the field side of the levee as the main objective; the expected co-benefits are as shown in Table 4. According to the simulation results and statistics on inundation area sizes of each case, all cases except case $\mathrm{D}$ are able to reduce agricultural losses caused by inundation.

Other factors to consider are cost, ecosystem service efficiency, and recreational value. Case $\mathrm{A}$ and case $\mathrm{E}$ will be more costly than the other cases, as case $\mathrm{A}$ employs high-strength levees and case $E$ employs land expropriation. Case $C$ can increase ecosystem service efficiency via the setting up of a wildlife corridor, and case $\mathrm{E}$ via the planting of local tree species in the floodplain area to enrich the landscape and the ecology. In case E, floodplains can also be planned as parks, detention wetlands, stadiums, or promenade facilities to serve recreational purposes.

Taking all benefits and co-benefits into account, this study suggests case $\mathrm{E}$ for the case area Nangang River; not only does case E provide good flood mitigation for low return period floods, but also increases ecosystem service efficiency and provides recreational areas for locals. 
Table 4. Expected co-benefits of $\mathrm{NbS}$ case.

\begin{tabular}{cll}
\hline Case & \multicolumn{1}{c}{ Outline } & \multicolumn{1}{c}{ Expected Co-Benefits } \\
\hline A & Extend the existing levees & Protection of farmlands and reduction of agricultural losses \\
& Prevention of agricultural land erosion
\end{tabular}

\section{Conclusions}

This study focused on the Nangang River area and developed and proposed five NbS cases. Cases A and B can be condensed as the act of extending the existing levees, case $\mathrm{C}$ as the act of adding discontinuous levees, case $\mathrm{D}$ as the act of dredging the main channel, and case E as the act of implementing "Room for the River". The PHD model was used to simulate the steady flow of each return period and compare the results of the simulations with the current situation.

Overall, case A has the best flood mitigation under all return period conditions, and the flood mitigation effects of the other cases are ranked in descending order as cases E, C, $\mathrm{B}$, and $\mathrm{D}$.

The core value and principle of $\mathrm{NbS}$ is to solve social challenges through nature-based means and increase biodiversity and ecological services at the same time. Cases $\mathrm{C}$ and $\mathrm{E}$ are good in this regard, as they can bring benefits to ecological services, while the co-benefits of cases A and B are relatively small. Taking both the expected benefits and co-benefits into account, this study believes that case $\mathrm{E}$ is most suited for improving flood disaster mitigation in the Nangang River area. It is still necessary to discuss with local stakeholders and obtain their consensus and support before the actual implementation of the case, so as to achieve the goal of "Living with nature, booming with water".

There may be negative impacts to the environment after the implementation of $\mathrm{NbS}$; constant monitoring and assessment of the environment will be required to establish the level of impact. It should be noted that uncertain negative impacts to the environment may be caused by the implementation of $\mathrm{NbS}$; constant monitoring and assessment of the environment will be required to establish the level of impact, if any. Another point to take note of is that the PHD model uses fewer cells to describe physiographic conditions in order to rapidly assess the flood mitigation benefits of each case. For areas with drastic changes to the elevation, water depth cannot be accurately described by a PHD model with fewer cells. If one wishes to increase the accuracy of simulations, this study recommends increasing cells in areas that fulfill the aforementioned criteria. 
Author Contributions: Conceptualization, W.L. and D.-J.D.; methodology, M.-H.W.; software, M.-H.W.; validation, C.-T.H. and M.-H.W.; formal analysis, C.-T.H. and M.-H.W.; investigation, M.-H.W. and D.-J.D.; resources, L.-H.T.; data curation, Y.-J.C.; writing-original draft preparation, C.-T.H.; writing-review and editing, M.-H.W.; visualization, M.-H.W.; supervision, W.L. and M.-H.W.; project administration, C.-H.C. All authors have read and agreed to the published version of the manuscript.

Funding: This research was funded by Water Resources Planning Institute, Water Resources Agency, Ministry of Economic Affairs, ROC(MOEAWRA1090267).

Institutional Review Board Statement: Not applicable.

Informed Consent Statement: Not applicable.

Data Availability Statement: Data are available from the corresponding author.

Acknowledgments: This study was supported by grants from the Water Resources Planning Institute, Water Resources Agency Ministry of Economic Affairs, ROC(MOEAWRA1090267). The authors gratefully acknowledge the support.

Conflicts of Interest: The authors declare no conflict of interest.

\section{References}

1. World Bank. Biodiversity, Climate Change, and Adaptation: Nature-Based Solutions from the World Bank Portfolio; World Bank Group: Washington, DC, USA, 2008.

2. IUCN. Guidance for Using the IUCN Global Standard for Nature-Based Solutions: First Editions, 1st ed.; International Union for Conservation of Nature: Gland, Switzerland, 2020. [CrossRef]

3. European Commission. Towards an EU Research and Innovation Policy Agenda for Nature-Based Solutions E Re-Naturing Cities; European Union: Luxembourg, 2015. [CrossRef]

4. WWAP (United Nations World Water Assessment Programme)/UN-Water. The United Nations World Water Development Report 2018: Nature-Based Solutions for Water; UNESCO: Paris, France, 2018.

5. Czemiel Berndtsson, J. Green roof performance towards management of runoff water quantity and quality: A review. Ecol. Eng. 2010, 36, 351-360. [CrossRef]

6. Shafique, M.; Kim, R.; Kyung-Ho, K. Rainfall runoff mitigation by retrofitted permeable pavement in an urban area. Sustainab ility 2018, 10, 1231. [CrossRef]

7. Davis, A.P.; Hunt, W.F.; Traver, R.G.; Clar, M. Bioretention Technology: Overview of Current Practice and Future Needs. J. Environ. Eng. 2009, 135, 109-117. [CrossRef]

8. Damodaram, C.; Giacomoni, M.H.; Prakash Khedun, C.; Holmes, H.; Ryan, A.; Saour, W.; Zechman, E.M. Simulation of combined best management practices and low impact development for sustainable stormwater management. J. Am. Water Resour. Assoc. 2010, 46, 907-918. [CrossRef]

9. Thorslund, J.; Jarsjo, J.; Jaramillo, F.; Jawitz, J.W.; Manzoni, S.; Basu, N.B.; Chalov, S.R.; Cohen, M.J.; Creed, I.F.; Goldenberg, R.; et al. Wetlands as large-scale nature-based solutions: Status and challenges for research, engineering and management. Ecol. Eng. 2017, 108, 489-497. [CrossRef]

10. Chou, R.-J. Achieving successful river restoration in dense urban areas: Lessons from Taiwan. Sustainability 2016, 8, 1159. [CrossRef]

11. Klijn, F.; de Bruin, D.; de Hoog, M.C.; Jansen, S.; Sijmons, D.F. Design quality of room-for-the-river measures in the Netherlands: Role and assessment of the quality team (Q-team). Int. J. River Basin Manag. 2013, 11, 287-299. [CrossRef]

12. Ruangpan, L.; Vojinovic, Z.; Di Sabatino, S.; Leo, L.S.; Capobianco, V.; Oen, A.M.P.; McClain, M.; Lopez-Gunn, E. Nature-Based Solutions for hydro-meteorological risk reduction: A state-of-the-art review of the research area. Nat. Hazards Earth Syst. Sci. 2020, 20, 243-270. [CrossRef]

13. Vojinovic, Z.; Alves, A.; Gómez, J.P.; Weesakul, S.; Keerakamolchai, W.; Meesuk, V.; Sanchez, A. Effectiveness of small- and large-scale Nature-Based Solutions for flood mitigation: The case of Ayutthaya, Thailand. Sci. Total Environ. 2021, $789,147725$. [CrossRef]

14. Wu, J.; Yang, R.; Song, J. Effectiveness of low-impact development for urban inundation risk mitigation under different scenarios: A case study in Shenzhen, China. Nat. Hazards Earth Syst. Sci. 2018, 18, 2525-2536. [CrossRef]

15. Huang, L.; Shao, Q.; Liu, J. Forest restoration to achieve both ecological and economic progress, Poyang Lake basin, China. Ecol. Eng. 2012, 44, 53-60. [CrossRef]

16. Chowdhury, M.S.N.; Walles, B.; Sharifuzzaman, S.M.; Hossain, M.S.; Ysebaert, T.; Smaal, A.C. Oyster breakwater reefs promote adjacent mudflat stability and salt marsh growth in a monsoon dominated subtropical coast. Sci. Rep. 2019, 9, 8549. [CrossRef] [PubMed]

17. Dilley, M.; Chen, R.S.; Deichmann, U.; Lerner-Lam, A.L.; Arnold, M. Natural Disaster Hotspots: A Global Risk Analysis; World Bank: Washington, DC, USA, 2005. 
18. Water Resources Planning Institute. A Review of Mainstream of Wu River System and Its Tributaries Nangang and Mei River Regulation Planning; Water Resources Planning Institute: Taiwan, China, 2017. (In Chinese)

19. Shiau, J.T.; Chen, C.-N.; Tsai, C.-H. Physiographic Drainage-Inundation Model Based Flooding Vulnerability Assessment. Water Resour. Manag. 2012, 26, 1307-1323. [CrossRef]

20. Yu, P.S.; Yang, T.C.; Kuo, C.M.; Tai, C.W. Integration of Physiographic Drainage-Inundation Model and Nondominated Sorting Genetic Algorithm for Detention-Pond Optimization. J. Water Resour. Plann. Manage. 2015, 141, 04015028. [CrossRef]

21. Wang, H.W.; Lin, C.W.; Yang, C.Y.; Ding, C.F.; Hwung, H.H.; Hsiao, S.C. Assessment of Land Subsidence and Climate Change Impacts on Inundation Hazard in Southwestern Taiwan. Irrig. Drain. 2018, 67, 26-37. [CrossRef]

22. Yang, C.J. Study on Construction of a Physiographic Inundation Forecasting System. Ph.D. Thesis, National Cheng Kung University, Tainan City, Taiwan, 2000.

23. Mishra, S.K.; Singh, V.P. Soil Conservation Service Curve Number (SCS-CN) Methodology; Springer, Water Science and Technology Library: Dordrecht, The Netherlands, 2003.

24. Chen, C.-N.; Tsai, C.-H.; Tsai, C.-T. Simulation of Sediment Yield from Watershed by Physiographic Soil Erosion-Deposition Model. J. Hydrol. 2006, 327, 293-303. [CrossRef] 